- News \& Views •

\title{
The Forgotten Nutrient-The Role of Nitrogen in Permafrost Soils of Northern China
}

\author{
Elisabeth RAMM ${ }^{1}$, Chunyan LIU*2, Xianwei WANG ${ }^{3}$, Hongyu YUE², Wei ZHANG², Yuepeng PAN², \\ Michael SCHLOTER ${ }^{4,5}$, Silvia GSCHWENDTNER ${ }^{5}$, Carsten W. MUELLER ${ }^{4,7}$, Bin HU6 \\ Heinz RENNENBERG ${ }^{6}$, and Michael DANNENMANN ${ }^{* 1}$ \\ ${ }^{1}$ Institute of Meteorology and Climate Research, Atmospheric Environmental Research (IMK-IFU), \\ Karlsruhe Institute of Technology (KIT), Garmisch-Partenkirchen 82467, Germany \\ ${ }^{2}$ State Key Laboratory of Atmospheric Boundary Layer Physics and Atmospheric Chemistry (LAPC), \\ Institute of Atmospheric Physics, Chinese Academy of Sciences, Beijing 100029, China \\ ${ }^{3}$ Key Laboratory of Wetland Ecology and Environment, Northeast Institute of Geography and Agroecology, \\ Chinese Academy of Sciences, Changchun 130102, China \\ ${ }^{4}$ Chair of Soil Science, Science Center Weihenstephan, Department of Ecology and Ecosystem Management, \\ Technical University Munich, Freising 85354, Germany \\ ${ }^{5}$ Research Unit for Comparative Microbiome Analyses, Helmholtz Zentrum München, \\ Oberschleissheim 85764, Germany \\ ${ }^{6}$ Center of Molecular Ecophysiology (CMEP), College of Resources and Environment, \\ Southwest University, Chongqing 400715, China \\ ${ }^{7}$ Department of Geosciences and Natural Resource Management, University of Copenhagen, \\ Copenhagen DK-1350, Denmark
}

(Received 4 February 2020; revised 3 April 2020; accepted 15 April 2020)

Citation: Ramm, E., and Coauthors, 2020: The forgotten nutrient-The role of nitrogen in permafrost soils of northern China. Adv. Atmos. Sci., 37(8), 793-799, https://doi.org/10.1007/s00376-020-0027-5.

\section{Introduction: permafrost carbon and nitrogen feedback to climate change}

Permafrost refers to any ground, including soils, sediments and rocks, with a temperature at or below the freezing point of water $\left(0^{\circ} \mathrm{C}\right)$ for two or more consecutive years (Biskaborn et al., 2019). Permafrost soils of the Northern Hemisphere store vast amounts of both organic carbon (C) and nitrogen (N) (Tarnocai et al., 2009; Harden et al., 2012; Mueller et al., 2015). Only in the uppermost $3 \mathrm{~m}$, soils in the northern permafrost zone contain $1035 \pm 150 \mathrm{Pg} \mathrm{C}$, corresponding to around one third of the $\mathrm{C}$ stocks in the uppermost $3 \mathrm{~m}$ of soils worldwide (Hugelius et al., 2013, 2014; Schuur et al., 2015). Due to global warming and permafrost degradation, large amounts of $\mathrm{C}$ previously stored in frozen organic matter have been released to the atmosphere in the forms of carbon dioxide $\left(\mathrm{CO}_{2}\right)$ and methane $\left(\mathrm{CH}_{4}\right)$ (Zimov et al., 2006; Schuur et al., 2009). The total $\mathrm{C}$ release resulting from permafrost degradation might be as high as $92 \pm 17 \mathrm{Pg} \mathrm{C}$ from now to 2100, with an estimated contribution by $\mathrm{CO}_{2}$ and $\mathrm{CH}_{4}$ of $97.7 \%$ and 2.3\%, respectively (Schuur et al., 2015). The feedbacks between climate change and permafrost $\mathrm{C}$ release are accelerated by the extraordinarily fast warming in arctic regions, occurring at a more than doubled pace compared to the global average (IPCC, 2014). Permafrost degradation with associated C release is thus assumed to be a key driver of global temperature increase in the 21st century (Schuur et al., 2013).

In contrast to the intensive levels of research having been carried out to address the permafrost $\mathrm{C}$ climate feedback (e.g., the Permafrost Carbon Network; http://www.permafrostcarbon.org/), research on permafrost soil $\mathrm{N}$ biogeochemistry and the associated release of the potent greenhouse gas $(\mathrm{GHG})$ nitrous oxide $\left(\mathrm{N}_{2} \mathrm{O}\right)$ under a changing climate is strongly lagging behind. Thus far, little is known about the fate of formerly protected organic $\mathrm{N}$ during thawing of permafrost soils that

\footnotetext{
* Corresponding author: Chunyan LIU, Michael DANNENMANN

Email: 1cy@ post.iap.ac.cn, michael.dannenmann@kit.edu
} 
store as much as $67 \mathrm{Pg} \mathrm{N}$ (Harden et al., 2012). Until recently, the soil N cycle in cold and pristine ecosystems was thought to be largely confined to organic $\mathrm{N}$ cycling due to the scarcity of $\mathrm{N}$ inputs, slow decomposition at low temperatures and high competition for bioavailable $\mathrm{N}$ between biota (van Cleve and Alexander, 1981; Schimel and Bennett, 2004). Thus, it has been postulated for a long time that $\mathrm{N}_{2} \mathrm{O}$ emissions from permafrost soils are low as a result of limited amounts of inorganic N (Rodionow et al., 2006; Chapin et al., 2011). However, over the last decade, a growing number of studies have reported very high $\mathrm{N}_{2} \mathrm{O}$ emissions from permafrost soils, which are in a comparable range as observed for tropical forests or agricultural ecosystems (e.g., Repo et al., 2009; Elberling et al., 2010; Marushchak et al., 2011; Palmer et al., 2012; Abbott and Jones, 2015; Voigt et al., 2017a; Liu et al., 2018; Wilkerson et al., 2019). In addition, the few available studies on experimental warming of permafrost soils hint at a stimulation of $\mathrm{N}_{2} \mathrm{O}$ emissions by temperature (Chen et al., 2017; Voigt et al., 2017a, b; Cui et al., 2018). The potential significance of inorganic $\mathrm{N}$ cycling and $\mathrm{N}_{2} \mathrm{O}$ release in permafrost soils can be illustrated by a simple calculation. If $10 \%$ of the organic $\mathrm{N}$ stored in permafrost soils (i.e., $6.7 \mathrm{Pg} \mathrm{N}$ ) is released between the present day and the year 2100, as it has been estimated for $\mathrm{C}$ release (Schuur et al., 2015), and only $1 \%$ is emitted as $\mathrm{N}_{2} \mathrm{O}$ (67 Tg N $\mathrm{N}_{2} \mathrm{O}-\mathrm{N}$ ), just like the IPCC's default $\mathrm{N}_{2} \mathrm{O}$ emission factor for $\mathrm{N}$ mineralized from mineral soils (IPCC, 2006), this would be equivalent to 10 times the global annual rate of $\mathrm{N}_{2} \mathrm{O}$ emissions from soils under natural vegetation $\left[6.6 \mathrm{Tg} \mathrm{N}_{2} \mathrm{O}-\mathrm{N}\right.$ yr ${ }^{-1}$ (Ciais et al., 2013)]. Consequently, there is an urgent need to better understand $\mathrm{N}$ biogeochemistry and associated gaseous $\mathrm{N}$ emissions in permafrost soils under the auspices of a warming climate.

\section{The Sino-German NIFROCLIM project}

The NIFROCLIM project (Soil nitrogen turnover and nitrous oxide emissions in permafrost landscapes of northern China in a changing climate; www.nifroclim.de) tackles the lack of research concerning soil $\mathrm{N}$ turnover and $\mathrm{N}_{2} \mathrm{O}$ emissions in permafrost landscapes. NIFROCLIM is a Sino-German project funded by the German Science Foundation (DFG) and the National Science Foundation of China (NSFC). The central goal of NIFROCLIM is to gain a process-based and functional understanding of (1) gross $\mathrm{N}$ turnover as well as associated $\mathrm{N}_{2} \mathrm{O}$ formation and consumption (i.e., reduction to dinitrogen gas) in the vertical soil profile; (2) differences in soil gross $\mathrm{N}$ turnover and $\mathrm{N}_{2} \mathrm{O}$ emissions across ecosystem transects in typical permafrost landscapes; and (3) the effects of warming and permafrost degradation on (1) and (2). Thus, NIFROCLIM aims at a strong contribution towards closing knowledge gaps on permafrost $\mathrm{N}$ biogeochemistry.

Therefore, NIFROCLIM combines (1) research on the quality and quantity of $\mathrm{N}$ in soil organic matter; (2) molecular measurements of the abundance and activity of soil microbes involved in the $\mathrm{N}$ cycle; (3) isotope-based quantitative biogeochemical process studies; and (4) measurements of $\mathrm{N}$ gas $\left(\mathrm{NO}, \mathrm{N}_{2} \mathrm{O}, \mathrm{N}_{2}\right.$ ) production in soil and the exchange at the soil-atmosphere interface in an interdisciplinary approach.

NIFROCLIM was launched with a kickoff meeting and a first campaign in the target region of Mohe County, Northeast China, in July 2019. The sampling concept in the research area encompasses (1) high-resolution soil and gas sampling in vertical soil profiles from the soil surface to the active layer and into the upper layers of the permafrost; (2) soil and vegetation sampling as well as GHG flux measurements across topographic landscape transects covering different upland forests and lowland bogs; and (3) investigations of climate change effects by using open top chambers (OTCs) to simulate warming.

\section{Study area and key scientific infrastructures}

Besides high-altitude and alpine permafrost on the Tibetan Plateau and in Northwest China $\left(1.35 \times 10^{6} \mathrm{~km}^{2}\right)$, there is a subarctic discontinuous permafrost region with an area of $0.24 \times 10^{6} \mathrm{~km}^{2}$ at the very northern end of China (Cheng and Jin, 2013). The latter permafrost region in Northeast China is part of the Eurasian permafrost complex-the world's largest permafrost area (Fig. 1a). Being located at the southern edge of the Eurasian permafrost complex, this region is sensitive to ongoing climate change, making it an ideal study area for research targeted at constraining predictions of GHG release from permafrost soils under global warming. The study sites of the NIFROCLIM project are located in the Fukuqi River catchment on the northern slope of the Great Hing'an Mountains $\left(\sim 105 \mathrm{~km}^{2}\right.$; Fig. 1b). The annual mean temperature and precipitation in this catchment are $-4.2^{\circ} \mathrm{C}$ and $425 \mathrm{~mm}$, respectively [1959-2013 (Guo et al., 2018)]. Bogs are distributed along the river valley and surrounded by birch (Betula platyphylla Suk.) or alder (Alnus sibirica Fisch. ex Turcz) groves. Dominant plant species in the ombrotrophic bogs include dwarf shrubs [B. fruticosa Pall., Ledum palustre L., Vaccinium uliginosum Linn., and Rhododendron lapponicum (L.) Wahl.), sedges (Eriophorum vaginatum L., and Carex globularis L.] and mosses (Sphagnum spp.). Most of the upland coniferous forests were destroyed during a forest fire in 1987 and hence replaced in the course of natural succession by secondary broad-leaved forests (B. platyphylla Suk.; 64\% of the upland forest area) and via planting of coniferous forests [Larix gmelinii (Rupr.) Kuzen. and Pinus sylvestris Linn. var. mongolica Litv.]. The flat (bogs and lowland groves) and hilly (upland forests) lands account for $29 \%$ and $71 \%$ of the catchment area, respectively. The growing season typically starts in mid-April to early May and ends in late September. The soils are classified as Cryic Histosols with a peat layer of 30 to $50 \mathrm{~cm}$ in bogs, and as Gelic Umbrisols with a thin soil layer of 10 to $30 \mathrm{~cm}$ in upland forests (IUSS Working Group WRB, 2015). Maximum active layer depths appear at the end of August to the beginning of 

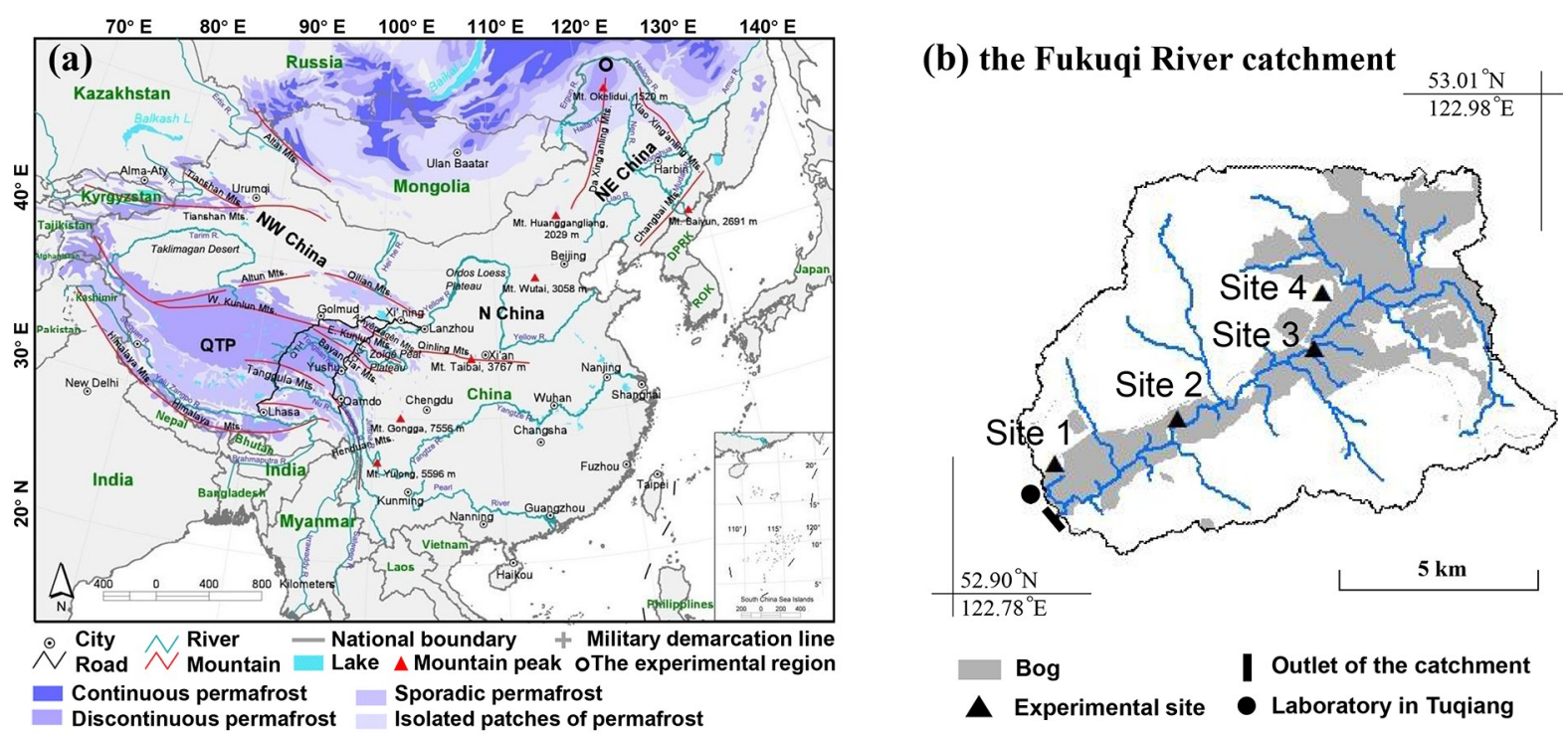

Fig. 1. (a) Map of permafrost-affected areas in China (Cheng and Jin, 2013) showing the Eurasian permafrost in the northeast. (b) Geographical location of the experimental region.

September, and range from 50 to $100 \mathrm{~cm}$ in bogs and from 80 to $150 \mathrm{~cm}$ in upland forests.

Scientific infrastructure has been established at four sites in the upper, middle and lower reaches of Fukuqi River to investigate permafrost $\mathrm{N}$ biogeochemistry and soil-atmosphere gas exchange (Fig. 1b). At the most extensively equipped Site 2, the effects of long-term warming are studied in situ, using OTC warming platforms in different habitats $(B$. fruticosa and $L$. palustre communities of ombrotrophic bogs) against controls outside the OTCs. The OTCs increase the soil temperature $\left(5 \mathrm{~cm}\right.$ depth) and active layer depth on average by $2^{\circ} \mathrm{C}$ and $7 \mathrm{~cm}$, respectively, during the growing seasons (Cui et al., 2018). At the same site, fully automated static chamber measuring systems with 12 chambers and an eddy covariance system allow for online quantification of $\mathrm{CO}_{2}, \mathrm{CH}_{4}$ and $\mathrm{N}_{2} \mathrm{O}$ fluxes at hourly temporal resolution [Figs. 2a and b (Liu and Zheng, 2019)] from March to November. To further address landscape-scale flux variations, manual static and dynamic chamber measuring systems are used to detect the soil-atmosphere $\mathrm{CO}_{2}, \mathrm{CH}_{4}, \mathrm{~N}_{2} \mathrm{O}$ and $\mathrm{NO}_{\mathrm{x}}$ fluxes at daily to sub-weekly temporal resolution at all sites in the catchment (overall > 100 flux chambers) (Figs. 2c and d) (Valente et al., 1995; Zhang et al., 2014).

Air samples from manual chamber measurements are analyzed by gas chromatography and a chemoluminescence NO$\mathrm{NO}_{2}-\mathrm{NO}_{\mathrm{x}}$ analyzer in the field laboratories at Tuqiang-a town at the outlet of the catchment (Fig. 1b). The laboratories at Tuqiang also offer basic equipment for extraction and stabilization of DNA from soils, which is needed to analyze the soil microbiome and to track soil microbial $\mathrm{N}$ transformations via molecular microbiological approaches. Moreover, at Tuqiang, soil samples including intact frozen soil cores are processed and labeled for stable isotope studies (Fig. 3) in order to quantify soil gross $\mathrm{N}$ turnover rates [protein depolymerization, ammonification, nitrification, microbial immobilization, biological $\mathrm{N}$ fixation (BNF)].

Topography, climate, land use, soil (e.g., soil texture, bulk density, $\mathrm{pH}$, total $\mathrm{N}$ and organic $\mathrm{C}$ contents), vegetation and management information are collected at the site or catchment scale to run the process-oriented hydrobiogeochemical model CNMM-DNDC [Fig. 4 (Zhang et al., 2018)]. Soil variables (e.g., temperature, moisture, dissolved organic C and inorganic $\mathrm{N}$ concentrations), soil-atmosphere gas fluxes, stream discharge and related dissolved $\mathrm{C}$ and $\mathrm{N}$ losses during runoff processes are measured to validate the model at the grid $(150 \mathrm{~m} \times 150 \mathrm{~m})$ or catchment scale. The hydrobiogeochemical model CNMM-DNDC will finally be used to upscale gaseous and dissolved $\mathrm{C}$ and $\mathrm{N}$ losses at the catchment scale, as well as to conduct scenario analyses of climate change to evaluate the influences of permafrost thawing on vegetation succession, permafrost $\mathrm{N}$ cycling and $\mathrm{N}_{2} \mathrm{O}$ emissions under the Representative Concentration Pathways.

\section{Supportive studies by other co-operation partners}

The presence of Alnus sibirica at the study sites urges the question of the role of BNF by symbiosis between the roots of this tree species and the $\mathrm{N}_{2}$-fixing bacteria Frankia spp. This is of particular significance for $\mathrm{N}$ cycling in permafrost soils, because Alnus is relatively deep-rooting and BNF requires large amounts of energy (Anand et al., 2012), which may enhance temperatures in the rhizosphere. These features might constitute an important $\mathrm{N}$ input into the ecosystem and could contribute significantly to below-ground $\mathrm{CO}_{2}$ fixation by the phosphoenolpyruvate carboxylase of alder roots (Fotelli et al., 2011). However, the relevance of BNF by the Alnus-Frankia complex for $\mathrm{N}$ cycling in permafrost soils, its temperature 

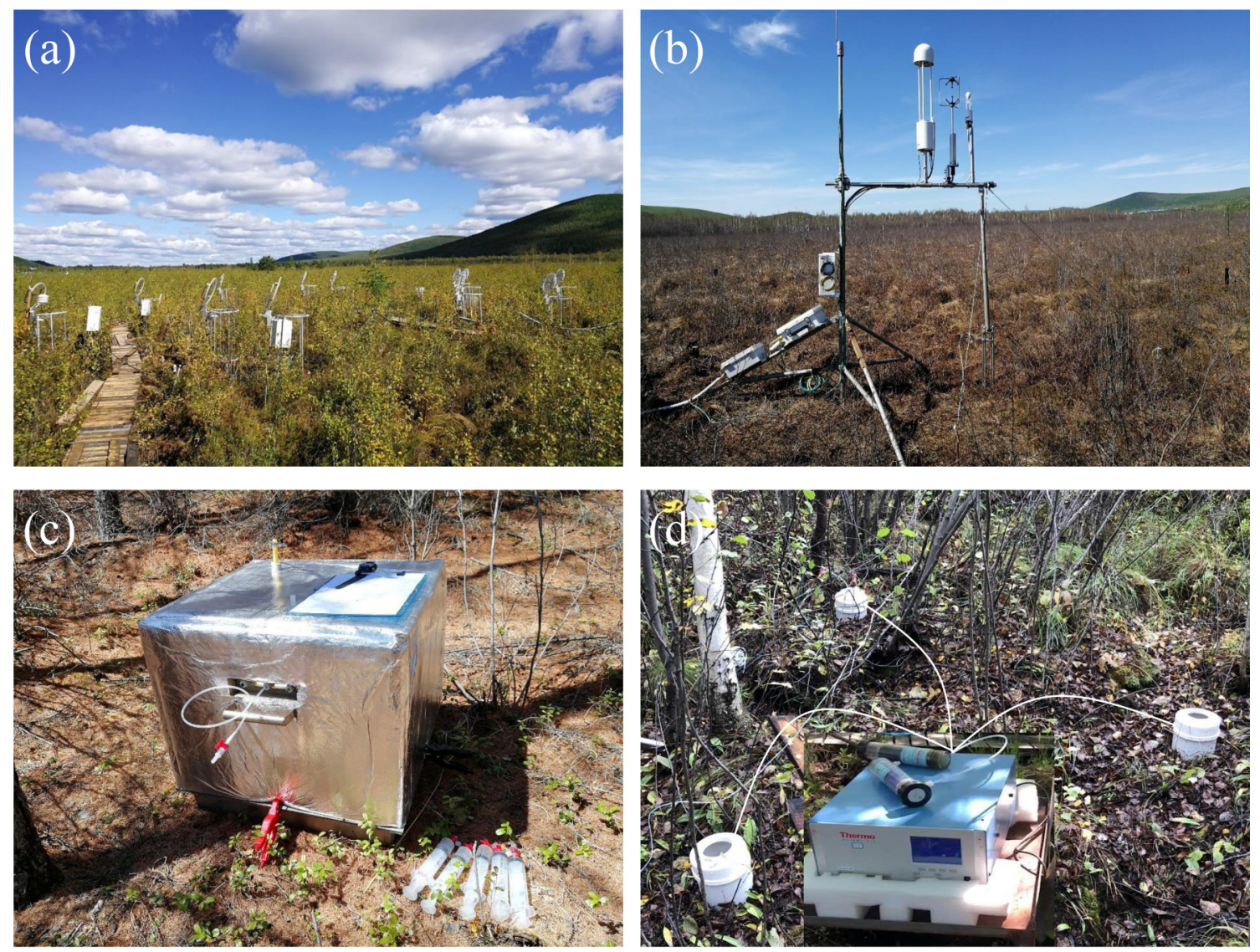

Fig. 2. The measuring systems used to quantify biosphere-atmosphere gas fluxes. (a) Automated static translucent chambers for measuring $\mathrm{CO}_{2}, \mathrm{CH}_{4}$ and $\mathrm{N}_{2} \mathrm{O}$ fluxes. (b) Eddy covariance system for measuring $\mathrm{CH}_{4}, \mathrm{CO}_{2}$ and water vapor exchanges. (c) Manual static opaque chambers for measuring soil respiration, $\mathrm{CH}_{4}$ and $\mathrm{N}_{2} \mathrm{O}$ fluxes. (d) Manual dynamic opaque chambers for measuring $\mathrm{NO}_{\mathrm{x}}$ fluxes.
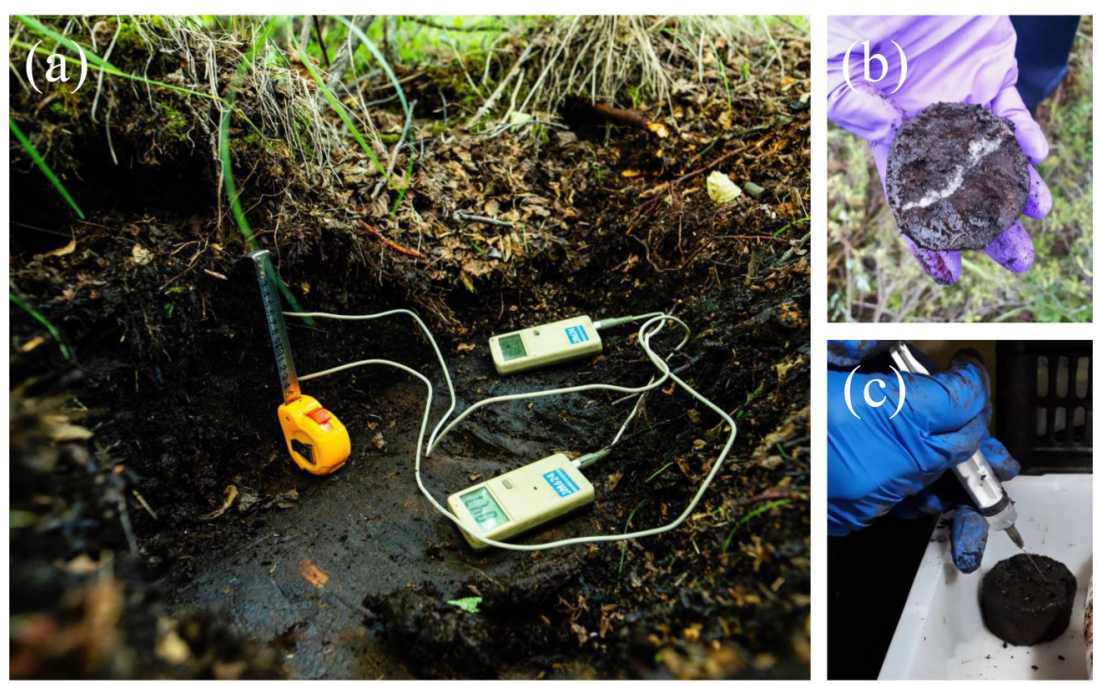

Fig. 3. Permafrost soil sampling. (a) Frozen ground at $\sim 20 \mathrm{~cm}$ depth in July 2019 at a wetland site with soil temperature measurement showing $4.7^{\circ} \mathrm{C}$ at $6.5 \mathrm{~cm}$ depth and $2.0^{\circ} \mathrm{C}$ at $14 \mathrm{~cm}$ depth. (b) Intact frozen soil core. (c) Labeling of frozen soil for stable isotope studies.

dependency, as well as the phosphoenolpyruvate carboxylase activity of Alnus roots, are largely unknown and require both basic research in the laboratory and extensive field studies. It is envisaged that such investigations will be performed in a cooperation with the Center of Molecular Ecophysiology (CMEP) of Southwest University, Chongqing, China. 


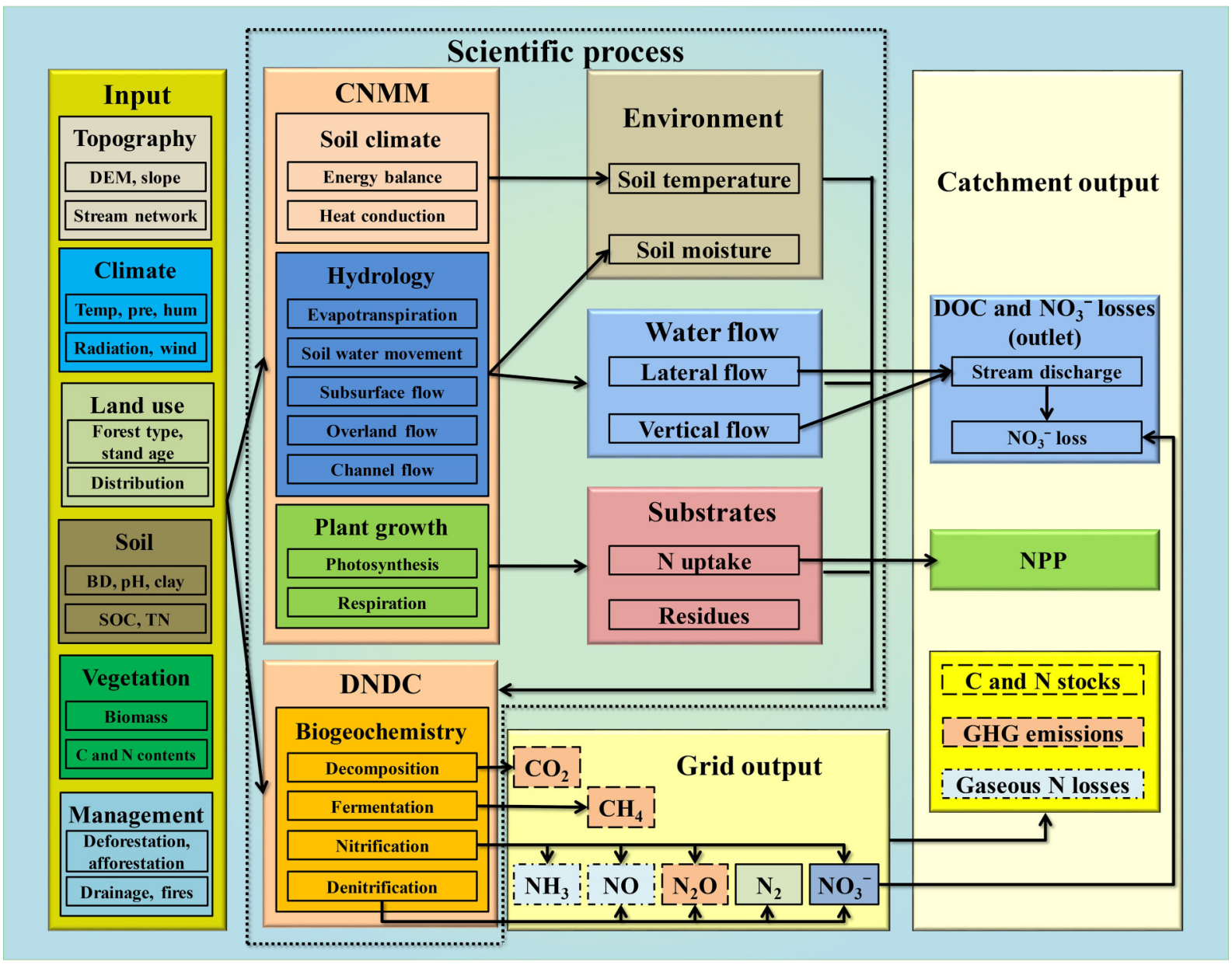

Fig. 4. The CNMM-DNDC model structure [Reprinted from Zhang et al. (2018)].

\section{Outlook}

In the near future, the NIFROCLIM consortium will focus on quantification of $\mathrm{N}$ inputs to permafrost ecosystems, i.e., (1) BNF by alder trees as well as Sphagnum mosses in ombrotrophic bogs, and (2) dry and wet atmospheric deposition of N at a catchment scale (Pan et al., 2012). Further foci will be (3) on disentangling the importance of soil organic versus mineral $\mathrm{N}$ as plant $\mathrm{N}$ sources, (4) the contribution of tree-mediated to ecosystem-level GHG emissions from the lowland birch and alder groves, and (5) to better understand the links between soil organic matter composition and the $\mathrm{N}$ cycle on permafrost-affected soils. In addition, laboratory studies are planned (6) to quantify soil $\mathrm{N}_{2}$ emissions and identify controls of $\mathrm{N}_{2}: \mathrm{N}_{2} \mathrm{O}$ emission ratios.

By combining the expertise of the researchers involved, the project is targeted at providing a comprehensive picture of the $\mathrm{N}$ cycle and $\mathrm{N}$ balances for the main ecosystems present in the permafrost region of Northeast China. Through the interdisciplinary cooperation between atmospheric physicists, soil biogeochemists, microbiologists, plant physiologists and soil scientists, NIFROCLIM aims at a holistic understanding of the permafrost soil $\mathrm{N}$ cycle and associated $\mathrm{N}_{2} \mathrm{O}$ emissions at a catchment scale under the auspices of climate change, and thus at providing a significant contribution towards a better prediction of potential $\mathrm{N}$ to climate feedbacks of permafrost ecosystems. In this context, NIFROCLIM is also seen as a platform for international cooperation on permafrost research in China and beyond.

Acknowledgements. Funding for the project is gratefully acknowledged and has been provided by the NSFC (Grant No. 41861134029) and DFG (Grant Nos. DA1217/4-1 and SCHL446/41-1).

\section{REFERENCES}

Abbott, B. W., and J. B. Jones, 2015: Permafrost collapse alters soil carbon stocks, respiration, $\mathrm{CH}_{4}$, and $\mathrm{N}_{2} \mathrm{O}$ in upland tundra. Global Change Biology, 21, 4570-4587, https://doi.org/10.1111/gcb.13069.

Anand, R., J.-C. Germon, P. M. Groffman, J. M. Norton, L. Philippot, J. I. Prosser, and J. P. Schimel, 2012: Nitrogen transformations. Handbook of Soil Sciences: Properties and Processes, 2nd ed., P. M. Huang et al., Eds., Taylor \& Francis Group, 2701-2753. 
Biskaborn, B. K., and Coauthors, 2019: Permafrost is warming at a global scale. Nature Communications, 10, 264, https://doi.org/10. 1038/s41467-018-08240-4.

Chapin III, F. S., P. A. Matson, and P. M. Vitousek, 2011: Principles of Terrestrial Ecosystem Ecology. 2nd ed., Springer, 529 pp.

Chen, X. P., G. X. Wang, T. Zhang, T. X. Mao, D. Wei, Z. Y. Hu, and C. L. Song, 2017: Effects of warming and nitrogen fertilization on GHG flux in the permafrost region of an alpine meadow. Atmos. Environ., 157, 111-124, https://doi.org/10.1016/j.atmosenv. 2017.03.024.

Cheng, G. D., and H. J. Jin, 2013: Permafrost and groundwater on the Qinghai-Tibet Plateau and in Northeast China. Hydrogeology Journal, 21, 5-23, https://doi.org/10.1007/s10040-012-0927-2.

Ciais, P., and Coauthors, 2013: Carbon and other biogeochemical cycles. Climate Change 2013: The Physical Science Basis. Contribution of Working Group I to the Fifth Assessment Report of the Intergovernmental Panel on Climate Change, T. F. Stocker et al., Eds. Cambridge University Press, 465-570.

Cui, Q., C. C. Song, X. W. Wang, F. X. Shi, X. Y. Yu, and W. W. Tan, 2018: Effects of warming on $\mathrm{N}_{2} \mathrm{O}$ fluxes in a boreal peatland of Permafrost region, Northeast China. Science of the Total Environment, 616-617, 427-434, https://doi.org/10.1016/j.scitotenv. 2017.10.246.

Elberling, B., H. H. Christiansen, and B. U. Hansen, 2010: High nitrous oxide production from thawing permafrost. Nature Geoscience, 3, 332-335, https://doi.org/10.1038/ngeo803.

Fotelli, M. N., D. Tsikou, A. Kolliopoulou, G. Aivalakis, P. Katinakis, M. K. Udvardi, H. Rennenberg, and E. Flemetakis, 2011: Nodulation enhances dark $\mathrm{CO}_{2}$ fixation and recycling in the model legume Lotus japonicus. Journal of Experimental Botany, 62, 2959-2971, https://doi.org/10.1093/jxb/err009.

Guo, Y. D., C. C. Song, W. W. Tan, X. W. Wang, and Y. Z. Lu, 2018: Hydrological processes and permafrost regulate magnitude, source and chemical characteristics of dissolved organic carbon export in a peatland catchment of Northeastern China. Hydrology and Earth System Sciences, 22, 1081-1093, https://doi.org/10.5194/hess-22-1081-2018.

Harden, J. W., and Coauthors, 2012: Field information links permafrost carbon to physical vulnerabilities of thawing. Geophys. Res. Lett., 39, L15704, https://doi.org/10.1029/2012GL051958.

Hugelius, G., and Coauthors, 2014: Estimated stocks of circumpolar permafrost carbon with quantified uncertainty ranges and identified data gaps. Biogeosciences, 11, 6573-6593, https://doi.org/10.5194/bg-11-6573-2014.

Hugelius, G., C. Tarnocai, G. Broll, J. G. Canadell, P. Kuhry, and D. K. Swanson, 2013: The Northern Circumpolar Soil Carbon Database: Spatially distributed datasets of soil coverage and soil carbon storage in the Northern permafrost regions. Earth System Science Data, 5, 3-13, https://doi.org/10.5194/essd-5-3-2013.

IPCC, 2006: $\mathrm{N}_{2} \mathrm{O}$ emissions from managed soils, and $\mathrm{CO}_{2}$ emissions from lime and urea application. 2006 IPCC Guidelines for National Greenhouse Gas Inventories, S. Eggleston et al., Eds., Cambridge University Press, 11 pp.

IPCC, 2014: Climate Change 2014: Synthesis Report. Contribution of Working Groups I, II and III to the Fifth Assessment Report of the Intergovernmental Panel on Climate Change, IPCC, $151 \mathrm{pp}$.

IUSS Working Group WRB, 2015: World reference base for soil resources 2014, update 2015: international soil classification system for naming soils and creating legends for soil maps. World Soil Resources Reports No. 106, 192 pp.

Liu, C. Y., and X. H. Zheng, Institute of Atmospheric Physics, Chinese Academy of Sciences, Chamber-based automatic system for monitoring gas fluxes: ZL201611077565.5 [P], 2019. 04. 23.

Liu, X.-Y., and Coauthors, 2018: Nitrate is an important nitrogen source for arctic tundra plants. Proceedings of the National Academy of Sciences of the United States of America, 115, 3398-3403, https://doi.org/10.1073/pnas.1715382115.

Marushchak, M. E., A. Pitkämäki, H. Koponen, C. Biasi, M. Seppälä, and P. J. Martikainen, 2011: Hot spots for nitrous oxide emissions found in different types of permafrost peatlands. Global Change Biology, 17, 2601-2614, https://doi.org/10.1111/j.13652486.2011.02442.x.

Mueller, C. W., J. Rethemeyer, J. Kao-Kniffin, S. Löppmann, K. M. Hinkel, and J. G. Bockheim, 2015: Large amounts of labile organic carbon in permafrost soils of Northern Alaska. Global Change Biology, 21, 2804-2817, https://doi.org/10.1111/gcb.12876.

Palmer, K., C. Biasi, and M. A. Horn, 2012: Contrasting denitrifier communities relate to contrasting $\mathrm{N}_{2} \mathrm{O}$ emission patterns from acidic peat soils in arctic tundra. The ISME Journal, 6, 1058-1077, https://doi.org/10.1038/ismej.2011.172.

Pan, Y. P., Y. S. Wang, G. Q. Tang, and D. Wu, 2012: Wet and dry deposition of atmospheric nitrogen at ten sites in Northern China. Atmospheric Chemistry and Physics, 12, 6515-6535, https://doi.org/10.5194/acp-12-6515-2012.

Repo, M. E., S. Susiluoto, S. E. Lind, S. Jokinen, V. Elsakov, C. Biasi, T. Virtanen, and P. J. Martikainen, 2009: Large $\mathrm{N}_{2} \mathrm{O}$ emissions from cryoturbated peat soil in tundra. Nature Geoscience, 2, 189-192, https://doi.org/10.1038/ngeo434.

Rodionow, A., H. Flessa, O. Kazansky, and G. Guggenberger, 2006: Organic matter composition and potential trace gas production of permafrost soils in the forest tundra in Northern Siberia. Geoderma, 135, 49-62, https://doi.org/10.1016/j.geoderma.2005.10.008.

Schimel, J., and J. Bennett, 2004: Nitrogen mineralization: Challenges of a changing paradigm. Ecology, 85, 591-602, https://doi.org/10.1890/03-8002.

Schuur, E. A. G., J. G. Vogel, K. G. Crummer, H. Lee, J. O. Sickman, and T. E. Osterkamp, 2009: The effect of permafrost thaw on old carbon release and net carbon exchange from tundra. Nature, 459, 556-559, https://doi.org/10.1038/nature08031.

Schuur, E. A. G., and Coauthors, 2013: Expert assessment of vulnerability of permafrost carbon to climate change. Climatic Change, 119, 359-374, https://doi.org/10.1007/s10584-013-0730-7.

Schuur, E. A. G., and Coauthors, 2015: Climate change and the permafrost carbon feedback. Nature, 520, 171-179, https://doi.org/10.1038/nature14338.

Tarnocai, C., J. G. Canadell, E. A. G. Schuur, P. Kuhry, G. Mazhitova, and S. Zimov, 2009: Soil organic carbon pools in the Northern circumpolar permafrost region. Global Biogeochemical Cycles, 23, GB2023, https://doi.org/10.1029/2008GB003327. 
Valente, R. J., F. C. Thornton, and E. J. Williams, 1995: Field comparison of static and flow-through chamber techniques for measurement of soil NO emission. J. Geophys. Res., 100, 21147-21152, https://doi.org/10.1029/95JD01875.

van Cleve, K., and V. Alexander, 1981: Nitrogen cycling in tundra and boreal ecosystems. Ecol. Bull., 33, 375-404.

Voigt, C., R. E. Lamprecht, M. E. Marushchak, S. E. Lind, A. Novakovskiy, M. Aurela, P. Martikainen, and C. Biasi, $2017 \mathrm{a}$ : Warming of subarctic tundra increases emissions of all three important greenhouse gases-carbon dioxide, methane, and nitrous oxide. Global Change Biology, 23, 3121-3138, https://doi.org/10.1111/gcb.13563.

Voigt, C., and Coauthors, 2017b: Increased nitrous oxide emissions from arctic peatlands after permafrost thaw. Proceedings of the National Academy of Sciences of the United States of America, 114, 6238-6243, https://doi.org/10.1073/pnas.1702902114.

Wilkerson, J., R. Dobosy, D. S. Sayres, C. Healy, E. Dumas, B. Baker, and J. G. Anderson, 2019: Permafrost nitrous oxide emissions observed on a landscape scale using the airborne eddy-covariance method. Atmospheric Chemistry and Physics, 19, 4257-4268, https://doi.org/10.5194/acp-19-4257-2019.

Zhang, W., C. Y. Liu, X. H. Zheng, Y. F. Fu, X. X. Hu, G. M. Cao, and K. Butterbach-Bahl, 2014: The increasing distribution area of zokor mounds weaken greenhouse gas uptakes by alpine meadows in the Qinghai-Tibetan Plateau. Soil Biology and Biochemistry, 71, 105-112, https://doi.org/10.1016/j.soilbio.2014.01.005.

Zhang, W., and Coauthors, 2018: A process-oriented hydro-biogeochemical model enabling simulation of gaseous carbon and nitrogen emissions and hydrologic nitrogen losses from a subtropical catchment. Science of the Total Environment, 616-617, 305-317, https://doi.org/10.1016/j.scitotenv.2017.09.261.

Zimov, S. A., E. A. G. Schuur, and F. S. Chapin III, 2006: Permafrost and the global carbon budget. Science, 312, 1612-1613, https://doi.org/10.1126/science.1128908. 